\title{
FORCED MARRIAGE: BIFURCATED VALUES IN THE UK $^{\#}$
}

\author{
Mary Welstead ${ }^{*}$
}

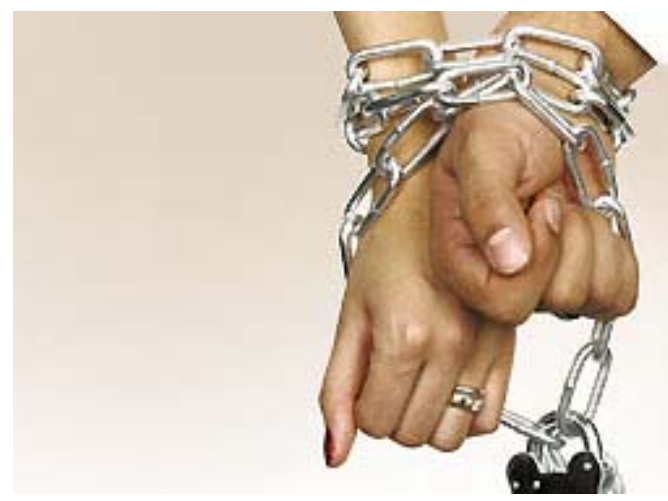

\section{JAMILA'S STORY}

I begin with a story because, in reality, most law, and particularly family law, is about stories, stories of human encounters. My story is about a 16year-old Muslim girl, let me call her Jamila (not, of course, her real name) who was born in England, and lived with her parents who originated from a small village in Asia. The family lived a very traditional life in England, alongside other families from a similar cultural background. Jamila's parents did not wish her to be contaminated by English values which seemed so far removed from their own.

Jamila's father was concerned that his daughter had suddenly started to wet the bed at night. He took her to see an English male doctor whose surgery was close to their home in Birmingham. Jamila arrived for her appointment, beautifully dressed in a traditional salwaar kameez made of silk and chiffon. Her father wished to remain with his daughter during the consultation with the doctor. However, the doctor insisted that he respect the confidentiality between doctor and patient, an accepted essential in England, and told the father that Jamila must be allowed to speak to him on her own. The father reluctantly capitulated.

\footnotetext{
\# This article is based on a talk given at CAP Harvard Law School in March 2009.

* Visiting Fellow CAP Harvard Law School, Visiting Professor University of Buckingham.
} 
The doctor very rapidly realised that Jamila was intelligent and exceptionally unhappy. He was familiar with her cultural background because of his experiences with many other similar immigrant families. He knew immediately the likely source of Jamila's problems and she confirmed that he was correct in his assumption. She admitted that her father had informed her that she was to marry her cousin in a few months' time. Jamila had never met the man and knew nothing about him. What she did know was that she wished to go to university and read English. She had tentative plans to embark on a future career in journalism.

Jamila was in a profound state of despair; she was in a 'no-win' situation. If she went along with her father's plan for marriage to her cousin, there would certainly be no freedom for her to pursue her own dreams. Marriage in her society meant that she would have to live with her husband and his relatives in an extended family. She would be controlled by them. Her future, a claustrophobic life as a married woman, looked bleak. However, if she objected to the marriage, she would risk suffering physical brutal treatment from her family; she would also risk emotional rejection by them. Bedwetting was her sub-conscious solution to her dilemma.

After his consultation with Jamila, the doctor met with her father and asked him what he thought was wrong with her. The father's response was that there was nothing wrong with Jamila other than her bedwetting. He remained silent about the fact that his real concern was that the bedwetting would interfere with his plans for Jamila's marriage. At that point the doctor reluctantly gave up any attempt to help, other than to prescribe medication for Jamila's symptom which, of course, did not address the real problem. He felt unable to do anything more because had he done so, he risked the father behaving in exactly the way Jamila feared.

The doctor also recognised, realistically, the emotional difficulties which faced a girl like Jamila from a strict Asian background. She had grown up in a world of bifurcated values. At school, she spent her days in an atmosphere of freedom and encouragement of self-determination. When she returned home she lived in a cultural environment which reflected the world from which her parents had originated, a world of parental control and unquestioning obedience. Jamila's dilemma was that she wanted to become personally fulfilled yet at the same time, she loved and respected her parents and the other members of her extended family. There was a security to living in that world even though its values stultified her. If she rebelled, she would face rejection by her family and the wider community which shared her parents' values. To whom then could she turn for support? Jamila did what she was supposed to do; she married in accordance with her parents' demands. ${ }^{1}$

In this article, I examine the issue of forced marriage in England and

\footnotetext{
${ }^{1}$ See Theodore Dalrymple “Reader, She Married Him - Alas” 1995 City Journal 1.
} 


\section{THE DENNING LAW JOURNAL;}

Wales (the jurisdiction) its extent, causes and consequences, and how the government has addressed the problem and with what success. ${ }^{2}$

\section{DEFINITION - FORCED NOT ARRANGED}

A forced marriage is one where one, or both, of the parties entered into it under duress. The force used may be either emotional or physical, or both.

The majority of these marriages involve girls under the age of eighteen although it is not unheard of for older women to be forced into marriage. The recent case of Dr Abedin, who was aged thirty-three, (see below) illustrates how parents may be able to trick or emotionally bribe even their adult offspring into marriage.

Whilst it is not unheard of for boys also to be forced into marriage against their wishes, there appear to be far fewer reports of males being coerced into marriage than there are female ones. The Forced Marriage Unit (see below) has reported that only $15 \%$ of the cases with which it deals involve males. Parents may attempt to force a male child to marry if they suspect that he is gay. The limited number of males who appear to be affected by the problem may, of course, be because men who have been forced to marry accept the situation and find alternate means of coping silently. Providing they appear to conform outwardly with parental wishes, they are more likely than women to have the freedom to continue to lead lives of their own choosing including indulging in extra-marital affairs. One young intelligent and well educated male, who received a message from his grandfather in Pakistan telling him that he was to marry a woman of his grandfather's choosing, decided that he could not rebel. However, he would continue the long-term relationship which he had with his English girlfriend and would, in effect, lead a polygamous existence once his marriage in Pakistan had taken place. ${ }^{3}$

The forced marriages may take place within the jurisdiction or in the country of parental origin. In some cases, victims have been tricked into travelling abroad, on the pretext that a holiday, or a family gathering, has been arranged. ${ }^{4}$ On their arrival, they are told that they are to be married. It is very difficult for a young person to rebel when he or she is in a strange place without financial resources or a passport (often confiscated by the parents on arrival in the country). There is no one to whom he or she may turn for help; the community is in this together with the parents.

\footnotetext{
${ }^{2}$ See generally, Hutchinson Hayward and Gupta "Forced Marriage Nullity Procedure in England and Wales” Brigitte Clark and Claudina Richards, Combating Forced Marriages: a Comparative Franco-English Perspective [2007] IFL 75; Ruth GaffneyRhys "Developments in the Field of Forced Marriage" [2008] IFL 26

${ }^{3}$ Personal communication.

${ }^{4}$ See NS v MI [2007] 1 FLR 444 (discussed below).
} 
Consummation of the marriage will, more often than not, take place immediately after the ceremony, frequently by force and under the influence of drugs. If it has taken place abroad, the young married couple will return to the UK, unless there are immigration issues to be resolved. If either of the parties is under the age of sixteen, the marriage will be void in the UK.

Arranged marriages are normally regarded as very different from forced marriages. The English judiciary has stated firmly that arranged marriages, where parents seek spouses for their children from their cultural community and allow their children a right of veto, are not to be condemned. ${ }^{5}$ They are seen as advantageous and are "to be respected and supported as a conventional concept in many societies." 6

However, the dividing line between forced marriages and arranged marriages can be a rather fine one. Young people who have been brought up to respect and obey their parents' wishes may find it difficult to object to an arranged marriage even where there are no threats of violence or overt emotional pressure. Their cultural beliefs may prevent them from even recognising the covert emotional force which is a feature of some arranged marriages.

\section{THE EXTENT OF THE PROBLEM}

As with many problems of a familial nature, it is not easy to state with confidence how prevalent forced marriage is. Many of the victims, quite understandably, do not discuss it openly; they are too afraid to do so. Many forced marriages are not categorised as such in government statistics. They are often hidden within crime statistics where they will be reported as incidences of domestic violence, rape, assault or murder. Others will be hidden in statistics relating to annulment of marriage.

One important, albeit limited, source of information comes from the Forced Marriage Unit. ${ }^{7}$ The Unit was set up, and funded, as a joint venture by the Foreign Office and Home Office in 2005, to deal with anyone, of any age,

\footnotetext{
${ }^{5}$ Readers might like to consider that many Western parents would prefer that their children married someone from a similar background, and do everything possible short of actually arranging a marriage, to ensure that this happens eg sending children to schools or universities where they are more likely to meet people from similar backgrounds, or living in certain areas with people from a similar social class.

${ }^{6}$ NS v MI [2007] 1 FLR 444. See also Re KR (A Child) (Abduction: Forcible Removal by Parents) - [1999] 4 All ER 954; Singer J "When is an Arranged Marriage a Forced Marriage?” [2001] IFL 30; Re SA (Vulnerable Adult with Capacity: Marriage) [2005] EWHC 2942 (Fam).

7 Foreign and Commonwealth Office UK Forced Marriage Unit http://www.fco.gov.uk/en/fco-in-action/nationals/forced-marriage-unit/
} 
who was involved with the reality, or possibility, of a forced marriage either within, or outside of, the jurisdiction. Since its inauguration, the Unit has helped to rescue 58 children, eleven of whom were under the age of sixteen. The youngest girl, aged eleven, was flown back to England from Dhaka, Bangladesh, after her parents had agreed to marry her to a Bangladeshi.

The Unit has seen a significant increase in the number of enquiries received. In 2008, there were 5,000 inquiries, $79 \%$ more than in 2007 . One third of these were from young people under the age of eighteen. In the same year the Unit's caseload was 400. Of these, 168 cases were related to marriages outside the jurisdiction, primarily in Pakistan, Bangladesh and India.

A more recent study, which was funded by the government, revealed that the incidence of forced marriage is almost certainly much greater than had been previously thought. The study which centred on Luton, a town with a high immigrant population found that more than 300 forced marriages were reported to various authorities, including the police and women's aid organisations, in one year alone. Dr Nazia Khanum, who was responsible for the study has suggested that the real number of forced marriages in the UK is likely to be closer to 4,000. The Luton report's victims were primarily Muslim women from families of Pakistani and Bangladeshi origin. ${ }^{8}$

Increasing awareness of the problem by the police, social workers, doctors, teachers, and a greater willingness of victims to report the abusive practice, alongside the enactment of the Forced Marriage Act 2008 (see below), means that more accurate statistical information is likely to become available in the future.

\section{EXPLANATIONS OF FORCED MARRIAGE}

It is frequently, and wrongly, assumed that those who force their children into marriage are motivated by religious fundamentalist ideals. However, there is no religion which imposes forced marriage on its believers. ${ }^{9}$ Adherence to these marriages stems from the cultural expectations, within sub-groups of certain immigrant communities who may argue that these cultural expectations have a religious element to them. Dr Nazia Khanum, in her report on her Luton study in 2008, stated that:

"Forced marriage is universally condemned, even by the perpetrators.

Few people openly support force in marriage. When it happens, the perpetrators do not say - or for the most part even believe - that they

8 Nazia Khanum "Forced marriage, Family Cohesion and Community Engagement: National Learning through a Case Study of Luton” (2008) //www.luton.gov.uk/.

${ }^{9}$ Lord Sheik, Hansard, Lords Debates, col 1332 (January 26 2007). 
are forcing their children into an unpleasant situation. They say and usually believe that their greater age, wisdom and experience give them a better understanding of their children's long term welfare than the children have themselves, and that their right to assert their authority to give their children a good start in life is sanctioned by custom, religion and common sense. The children's resistance only corroborates their immaturity." 10

Forcing ones children to marry may be seen as a form of bullying behaviour and like many other types of physical or emotional bullying conduct, is motivated, to a great extent, by fear.

Members of these sub groups remain fiercely attached to the cultural values which were inculcated in them during their own upbringing within their cultural group in their countries of origin. They are fearful of losing their cultural identity as a consequence of coming to live in the jurisdiction. There is a cultural expectation that daughters will live at home, and be taken care of, until they marry. They may be seen as an economic burden to the family, a burden which will be relieved only by marriage. Parents fear that their children will accept the values which they are subject to at school and, in particular, that their daughters will be at risk of finding unsuitable boy friends, and indulging in pre-marital sex, which might ruin any possibility of a marriage for any of their children within their cultural community. The sooner after puberty their daughters are married, the less chance there will be of this happening. Perhaps, even more worrying is the practice of parents attempting to organize marriages abroad for their mentally handicapped children who would find it difficult to find a partner in the UK. ${ }^{11}$

If children reject their traditional values, parents fear that they will become estranged from them. Who will then care for them in their old age?

These fears are further reinforced by the fact that those who engage in the practice of forced marriage tend to live in tight knit communities which consist, primarily, of families from similar cultural backgrounds. The community is an important source of help and stability and a reminder of the 'home' which they have left behind. Parents would rather make their children conform than risk criticism and rejection by the community.

One must not ignore other economic explanations of forced marriage. It can be seen as a medium of exchange which may be used to amass, or retain, wealth, particularly so when the marriage is between members of the same extended family. Marriages may also be used to create, or redeem debts between families. They permit access to British nationality for potential

\footnotetext{
${ }^{10}$ See above $n 8$.

${ }^{11}$ X City Council $v$ MB and others [2007] 3 FCR 371; Re SK (An Adult) (Forced Marriage: Appropriate Relief) [2005] All ER (D) 130 (Feb).
} 


\section{THE DENNING LAW JOURNAL;}

migrants from the parents' home country. This has a high financial value and may be a very valuable bargaining tool in family wealth creation.

\section{CONSEQUENCES}

Forced marriages have very serious consequences for their victims. ${ }^{12}$ By their very nature, they involve emotional violence, and, more often than not, physical violence also. ${ }^{13}$ Rape and other forms of sexual abuse are common. Where the forced marriage is with an older man, young women, who lack any education relating to sexually transmitted disease, are at risk of infection. They are reluctant to ask questions about the man's previous sexual history, and men tend not to be governed by the same strict rules, which relate to sexual behaviour, as are women.

Victims become isolated from their school peer group and friends. Their education is disrupted because they are removed from school to be married abroad. They are more likely to have children soon after marriage and are less likely to seek medical care or help from social services. They become economically dependent on their spouse, and his family with whom the couple will live, if the family is resident in the jurisdiction. This makes it even more difficult for young women to leave an unsatisfactory marriage. They risk being ill treated by the extended family. ${ }^{14}$

Where a woman is particularly recalcitrant and tries to escape from a forced marriage, severe physical brutality and even murder is not unknown. ${ }^{15}$

Many victims are abducted and become prisoners of their families. In 2008, an NHS doctor, Dr Humayra Abedin, who was aged 33, received a telephone call informing her that her mother was seriously ill. She returned to Bangladesh but on her arrival realised that it was a ruse in order to force her to marry a Bangladeshi man, so she alerted friends in England via a text message. When a Bangladeshi human rights organization, Ain O Salish Kendra (ASK), came looking for her at the family home, her family arranged for her to be removed. Her hands were tied behind her back and her head was covered with a cloth. She was bundled into an ambulance afraid that she

\footnotetext{
12 See eg Geetanjali Gangoli, Melanie McCarry, Amina Razak "Child Marriage or Forced Marriage, South Asian Communities in North East England” (2008) and Children \& Society www.stopvaw.org/Stop_Violence_Against_Women.html and Forced Marriage Inquiry [2008] IFL 76.

${ }^{13}$ Re K; A Local Authority v N and Others [2005] EWHC 2956 (Fam).

${ }^{14}$ Anushka Asthana and Ushma Mistry, The Observer 5 October 2003.

${ }^{15} R$ v Nazir [2009] All ER (D) 218; Ursula Smartt, Honour Killings (2006) 170 JPN 4; M Welstead and S Edwards "Death Before Familial Dishonour” (1999) New Law Journal 149 867; Girl Found Dead in River, The Guardian, Wednesday 9 January 2008.
} 
would be killed. She arrived at a psychiatric hospital where she was injected daily with psychiatric drugs for two months. The Bangladeshi court acting on a Forced Marriage Act order (see below), issued by the English court, ordered her release and she returned to England. ${ }^{16}$

Many young women, who are no longer virgins, either because they are sexually experienced or because their hymen has been damaged for other reasons, are terrified of a forced marriage. They are afraid that their lack of virginity will be discovered and this will lead to further punishment. To avoid sanctions, such women may seek hymenoplasty, more commonly known as re-virginisation surgery. ${ }^{17}$

\section{THE WAY FORWARD}

Until 1999, the UK government showed a certain reluctance to acknowledge the severity of the problem of forced marriages. It believed that the existing criminal law relating to domestic violence, assault and sexual offences were adequate solutions to the problem. Multiculturalism was the watchword of the day and there was a concern that the values of immigrant communities should be respected wherever possible. ${ }^{18}$ This approach left young women unprotected from the more extreme values of the immigrant sub-groups to which they belonged. Furthermore, it ignored the fact that the young people involved were reluctant to have recourse to criminal law. They did not wish to criminalise their families; they only wished their behaviour to stop.

However, in 1999, three separate incidents occurred which led the government to question whether a new way forward was necessary. A young Asian woman, Rukshana Naz, was violently murdered by her brothers and mother in Derby. Rukshana had become pregnant by her British lover having left her husband behind in Pakistan after she had been forced to marry there. ${ }^{19}$ A second couple known as 'Jack' and 'Zena' Briggs, it was revealed by the British press, were moving from hiding place to hiding place because Zena

\footnotetext{
${ }^{16}$ The Times, December 192008.

${ }^{17}$ M Welstead "The Virtue of Virginity” (2009) New Law Journal 159 No 7353 95; In Europe, Debate Over Islam and Virginity New York Times, June 11 2008; Why One Muslim Girl Became a Born-again Virgin for her Wedding 17 December 2007, Daily Mail.

${ }^{18}$ D Gillborn, D Youdell and A Kirton, "Government Policy and School Effects: Racism and Social Justice in Policy and Practice" Multicultural Teaching vol 17, Summer 1999 11; Gender equality, cultural diversity: the British experience; Moira Dustin and Anne Phillips, Cultural Diversity: European Comparisons Paper prepared for workshop on Gender Equality Amsterdam, June 8-9 2004.

${ }^{19}$ M Welstead and S Edwards "Death Before Familial Dishonour" (1999) New Law Journal 149867.
} 


\section{THE DENNING LAW JOURNAL;}

had refused to marry her Pakistani cousin. Her family had employed private detectives to find the couple. They did not succeed but the couple's life had been made very difficult by the family's action. ${ }^{20}$ In a third case, a young woman KR, aged sixteen, left her parents home and went to live with P, her older sister who had already fled the family home. KR's father complained to the police that $\mathrm{P}$ had, in effect, kidnapped KR. The police helped to return KR to her father who promptly removed her to India to the home of a relative. KR wrote to P, explaining that her father had beaten her and pleading for help. P applied to the English court for KR to be made a ward of court. The judge agreed to ward KR and asked the Indian authorities to find KR's put her in touch with the British High Commission. KR persuaded her guards to take her to the High Commission and she was returned to England. KR remained a ward of court. Singer $\mathrm{J}$ wanted his judgment to be made clear to parents who contemplated forcing their children to marry and to the relevant ethnic and religious communities. He also wished to ensure that local authorities and others in a position to protect the interests of children took their duties seriously. ${ }^{21}$

The government finally accepted that the problem needed to be addressed more specifically and existing civil and criminal remedies required to be reinforced by other measures. After wide reaching consultation, ${ }^{22}$ the Forced Marriage Unit was set up in 2005, as a joint venture between the Home Office and the Foreign and Commonwealth Office. Its remit is to assist all those who are at risk of a forced marriage, or have actually been forced into one, either in the UK or abroad. It also takes responsibility for providing information for social workers, teachers, health professionals and police who come into contact with cases of forced marriage.

The Unit's website and publications provide comprehensive, and comprehensible information, giving practical advice to those at risk. It provides a dedicated confidential telephone helpline which can be accessed from the UK and abroad. The helpline is operated by trained caseworkers who understand the emotional, cultural and social issues surrounding forced marriage.

The materials produced by the Unit's materials warn young people of the risks of being taken to their parents' country of origin. They may find themselves isolated; facing intense emotional pressure; being watched all the time; having no money, or passport or; return airline ticket, and having no

${ }^{20}$ Amelia Hill "Runaways Stalked by Bounty Thugs - Asian Families Pay Violent Hunters Thousands to Track Down Daughters” The Observer, 18 April 2004.

${ }^{21}$ Re KR (A Child) (Abduction: Forcible Removal by Parents) [1999] 4 All ER 954 at 955. See also Re SK (An Adult) (Forced Marriage: Appropriate Relief) [2005] All ER (D) 130 (Feb).

22 “Forced Marriage: A Wrong not a Right” (FCO/Home Office, 2005). 
access to a telephone. The Unit advises them to leave contact, passport and flight details with a friend in the UK whom they can trust. They are also advised to carry with them the contact details of the nearest UK Embassy, High Commission or Consulate, and to try and take some money with them.

If a forced marriage has already taken place, the Unit advises young people how to have the marriage annulled and how it may be possible to prevent a foreign spouse from obtaining entry to, or a right to reside in, the UK.

Where necessary, the Unit helps young people to obtain replacement passports, flights and return to the UK. If appropriate, a safe house will be found for them. The Unit encourages victims to see the actions of their families as criminal conduct in spite of the fact that many victims are reluctant to do so. They may not wish to be forced into marriage but they also want to keep open the possibility of a relationship with their family in the future.

Now that the issue has been brought fully out into the open, the police, social workers, teachers and doctors are more aware of how to deal sensitively with young people at risk. Teachers, in particular, have an important role to play. Significant absence from school is one of the signs that a pupil is at risk of, or has been removed to another country for the purposes of, a forced marriage. Efforts have been made to recruit the above professionals from the immigrant community who will understand, but not collude with the community and parents over forced marriages. Rather they will help to identify victims and support them whilst, at the same time, endeavour to help parents understand the need for their children to remain in education and be allowed the right to self-determination. ${ }^{23}$

It is of note that a poster produced by the Forced Marriage Unit illustrating the horrors of forced marriage, has been rejected by some head teachers in immigrant areas. They have argued that it is offensive to minority communities. The poster shows young persons' hands adorned with wedding rings but wrapped in locked chains. ${ }^{24}$ Other organisations within immigrant communities, run by people who have experienced forced marriages, have proliferated in those cities where young people are most at risk. They have taken a robust approach to the problem. ${ }^{25}$

Further efforts have been, and are being, made by the government to develop a multi -faceted approach to the prevention of forced marriages. In

\footnotetext{
${ }^{23}$ New help lines have been set up as a result o this increased awareness. See eg www.stophonourkillings.com/.

${ }^{24}$ See Select Committee on Home Affairs, Sixth Report Tuesday 14 April 2009 www.parliament.uk

25 See eg www.karmanirvana.org.uk/; Nazia Khanum, "Forced Marriage, Family Cohesion and Community Engagement: National Learning through a Case Study of Luton” www.luton.gov.uk/.
} 


\section{THE DENNING LAW JOURNAL;}

November 2008 the minimum age for marriage visas was increased from eighteen to twenty-one years. The stated aim of this change was to protect young people from forced marriages at an age when they could be establishing a degree of independence as an adult through further education or through work. ${ }^{26}$ This is of limited help because it will do nothing to help victims who marry older men but it has sent a clear message to parents contemplating marrying their children to other young people living abroad. They will not have the right of entry to the UK.

A new Code of Practice was published in March 2009 setting out how an application for a marriage visa or leave to remain in the United Kingdom as a husband or wife will be decided if someone is identified as vulnerable to a forced marriage. Indefinite leave to remain will be revoked which means the foreign national who is a party to the marriage will be liable to expulsion from the country. ${ }^{27}$

Further plans are afoot to introduce a requirement for British citizens and permanent residents who are seeking to sponsor a spouse to come to the UK to declare their intention before leaving the UK and marrying abroad. ${ }^{28}$

UK Government representatives hold regular consultations with their counterparts and the judiciary of those countries where forced marriages of British citizens are likely to take place. ${ }^{29}$ Mirpur District in Pakistan is one particular area where good relations have been forged. The Mirpur police provided British officials, from the High Commission, with guards equipped with AK47 machine guns to rescue one schoolgirl from Leeds from the threat of a forced marriage in a rural village in Mirpur. The girl had not been able to attend school and wanted to return to her mother in the UK. Her father had taken her to Pakistan after he left the mother. She had been beaten by him and was afraid of further beatings. She could not escape because in that part of Pakistan, any unaccompanied female would be challenged and stopped if she were to attempt to leave the village.

The diplomatic team, which rescued her, had a British court order,

\footnotetext{
${ }^{26}$ www.ukba.homeoffice.gov.uk.

${ }^{27}$ Ibid.

28 Ibid.

${ }^{29}$ In February 2009, the UK's Minister responsible for Consular Affairs including Forced Marriage, Gillian Merron MP, arrived in Pakistan on her first trip to the country to learn about the work of the High Commission relating to forced marriage. She said that "we can only help victims here because of the excellent co-operation we get from the local authorities in Pakistan. Without the help of the police we would not be able to help those at risk get back to safety. Without the understanding of local community leaders we would not be able to raise awareness of the help available to victims. And without the support of the Government of Pakistan we would not be able to successfully help people escape the terrible future they face." http://ukinpakistan.fco.gov.uk/en/working-with-pakistan/ministerial-visit.
} 
endorsed by a Pakistani judge, to return the girl to her mother. A friend had raised the alarm, and the girl's mother contacted the Forced Marriage Unit who alerted the team in Islamabad. They arranged their visit whilst the father was out of the country on business. The girl was taken back to a women's refuge in Islamabad and 48 hours later was on a plane back to England. ${ }^{30}$

In 2007, the government enacted the Forced Marriage (Civil Protection) Act. ${ }^{31}$ Lord Lester introduced a private members bill because the government had dragged its heels about legislating on this issue. The bill ultimately won the support of all parties. The Foreign and Commonwealth Office played a key role in during the bill's passage through parliament. It is too early to gauge the effect of the Act. Critics have argued that it lacks teeth because it does not make forced marriage a crime. ${ }^{32}$ Nevertheless, the Act has drawn attention to the problem, and some perpetrators of forced marriages may now be deterred by the possibility that their previous covert behaviour will become publicised by means of court hearings. The Act may also persuade victims to come forward in the knowledge that their action will not result in a criminal prosecution of their parents. It is to be noted that Dr Abedin, who was the first person to be rescued under the new Act, asked that her parents not be punished for their conduct.

The Act amends the Family Law Act 1996 and inserts a new Part 4A into the 1996 Act. It provides for applications for a Forced Marriage Protection Order (FMPO) not only by victims of forced marriages and those at risk of a forced marriage, but also by organizations seeking to help victims. Family members may also apply if they are granted permission by the court.

An FMPO may be made not only against the person or persons who are forcing someone to marry but also against third parties who are associated with the coercion. The orders may contain a power of arrest.

The orders are open ended and dependent on the circumstances and may relate to conduct which takes place in the UK or abroad. The courts, therefore, have a wide range of options open to them such as seizing the respondent's passport; requiring the respondent to reveal the whereabouts of a victim; preventing the respondent having contact with the victim; allowing the victim

${ }^{30}$ Daily Telegraph, January 62009.

${ }^{31}$ For a critique of the Act, see Ruth Gaffney-Rhys "Developments in the Field of Forced Marriage” [2008] IFL 26.

32 Bashir Ahmad, an MSP has stated that: "If forced marriages were a criminal offence it would be a real deterrent and I will be bringing forward a Private Members Bill on this." Osama Saeed, chairman of the Scottish-Islamic Foundation, said "I cannot help but feel this [decline in forced marriage] would be speeded along by effective legislation in the area.... MPs took the view that it [criminal legislation] may stop victims coming forward to seek help if a parent would go to jail as a result. I don't see why criminality can't be an option, with it being left to the victim whether or not to press charges.” Scotland on Sunday, March 232008. 


\section{THE DENNING LAW JOURNAL;}

to assume a new identity; ordering that a marriage may not take place; ordering the respondent that the victim may not be taken out of the country, and granting a personal protection order.

The law relating to nullity of marriage has become of increasing importance in the battle against forced marriage. More young people have begun to realise that they do not have to remain in a marriage to which they did not consent. Any person who is able to show that he or she did not consent to a marriage will be able to have it annulled. The marriage will be voidable rather than void which means that the petitioner must request the court to annul the marriage, unless, of course, the petitioner was under age at the time of the marriage. In the latter case, the marriage will be void ab initio and no court hearing will be necessary.

In NS $v M I,{ }^{33}$ Munby $\mathrm{J}$ reviewed the law relating to nullity of marriage in the context of a forced marriage. The petitioner, a young British girl, had lived in the UK all her life. When she was aged sixteen, she was taken to Pakistan by her mother under the pretext that she was going for a holiday. Her parents reassured her before they left the UK that she would not be married whilst she was there. Their daughter had actually questioned them about the possibility. The young girl rapidly realised that she had been lied to, and repeatedly asked to be allowed to return home to the UK. Her mother told her that she must remain in Pakistan until her father arrived for a holiday, and confiscated her daughter's passport. After several months, her father did arrive and she was told that her parents would kill themselves if she did not marry her first cousin, a young Pakistani aged seventeen, whom she had never met before. She was also told that she would never return to the UK unless she went ahead with the marriage. The cousin told her that the marriage was merely a ploy to allow him to enter the UK. The marriage went ahead and the girl moved into the boy's home for one week but did not consummate the marriage. She returned to her mother's house in Pakistan and several months later, after much pleading, returned to the UK with her mother, and had no further contact with her husband. Four years later she sought a decree of nullity and maintained that her family had morally blackmailed her and pressurised her into marriage. Her family, by this stage, had accepted that the marriage was a mistake. They supported the daughter in her application to have her marriage annulled. The Pakistani husband did not object.

Section 12(c) of the Matrimonial Causes Act 1973 provides that:

33 [2007] 1 FLR 444. 
“A marriage ... shall be voidable on the ... ground ... that either party to the marriage did not validly consent to it, whether in consequences of duress, mistake, unsoundness of mind or otherwise". ${ }^{34}$

Many of the earlier cases required the petitioner to prove that their apparent consent to the marriage was brought about by a threat of immediate danger to life, limb or liberty. ${ }^{35}$ It is doubtful whether that was ever good law, ${ }^{36}$ and is certainly no longer the case today, as Munby $\mathrm{J}$ made clear. The test is whether the duress experienced was such as to destroy the reality of consent and override the will of the petitioner. One judge has described the test more poetically in the words of the Greek poet Euripides, in Hippolytus, "my tongue has sworn, but no oath binds my mind." ${ }^{37}$ Whether the relevant duress has occurred or not is a subjective, and not an objective test; thus, the personality and circumstances of the petitioner is of the utmost importance. ${ }^{38}$

Munby $\mathrm{J}$ acknowledged that parental influences may be very subtle and reiterated his words from $\operatorname{Re} S A$ (Vulnerable Adult with Capacity: Marriage):

"where the influence is that of a parent or other close and dominating relative, and where the arguments and persuasion are based upon personal affection or duty, religious beliefs, powerful social or cultural conventions, or asserted social, familial or domestic obligations, the influence may, as Butler-Sloss LJ put it in In re T (Adult: Refusal of Treatment), be subtle, insidious, pervasive and powerful. In such cases, moreover, very little pressure may suffice to bring about the desired result." 39

Munby $\mathrm{J}$ was anxious to ensure that, particularly, where a petition for nullity is undefended, the petitioner is not merely attempting to escape from a

${ }^{34}$ S 13(2) of the Matrimonial Causes Act 1973 provides that proceedings must be instituted within 3 years from the date of the marriage. After 3 years have expired a petition can only be lodged if leave of the court is obtained under s 13(4) of the Act. N 2000, the Report of the Working Group on Forced Marriage pointed out that victims are often married young and "lack the confidence to challenge their situation" in the first years of marriage (p 7) www.fco.gov.uk/resources/.

${ }^{35}$ See eg Szechter (orse Karsov) v Szechter [1971] P 286, Singh v Singh [1971] P 226 and Singh v Kaur (1981) 11 Fam Law 152.

${ }^{36}$ See eg Hirani $v$ Hirani (1982) 4 FLR 232, $P$ v R (Forced Marriage: Annulment: Procedure) [2003] 1 FLR 661.

${ }^{37}$ Staughton LJ in In re T (Adult: Refusal of Treatment) [1993] Fam 95 at 121.

${ }^{38}$ Scott (falsely called Sebright) $v$ Sebright (1886) 12 PD 31 at 24.

${ }^{39}$ [2006] 1 FLR 867, at para 78. See also Allcard v Skinner (1887) 36 ChD 145 at 183 which discussed the relevance of emotional pressure in annulment cases. For In re T see [1993] Fam 95 at 120. 


\section{THE DENNING LAW JOURNAL;}

perfectly lawful and proper marriage which has turned out to be tiresome. ${ }^{40}$ However, he made clear that courts must be alert to the serious matter of forced marriage, which he saw as more prevalent than many would like to believe, and make a robust response to it.

He also stressed that:

"We must guard against the risk of stereotyping. We must be careful to ensure that our understandable concern to protect vulnerable children (or, indeed, vulnerable young adults) does not lead us to interfere inappropriately - and if inappropriately then unjustly - with families merely because they cleave, as this family does, to mores, to cultural beliefs, more or less different from what is familiar to those who view life from a purely Euro-centric perspective." 41

Munby J was concerned that a sensitive understanding should be shown to petitioners with respect to the requirement that annulment cases should be held in open court. He explained that there might be circumstances where a petitioner might be reluctant to give evidence if certain people, such as those responsible for the duress, were to be present in court; she might be placed at risk. In those cases it would be possible for the petitioner's evidence to be give behind a screen or via a video link.

He also emphasized the protection which the criminal law could provide in the context of forced marriages which was spelt out in the government's consultation paper, "Forced Marriage: A Wrong not a Right." ${ }^{42}$ He mentioned that in one county court case, a Sikh woman was awarded statutory damages of £35,000 under the Protection from Harassment Act 1997. The judge described her treatment at the hands of her mother-in-law as "four months of

\footnotetext{
${ }^{40}$ See Scott (falsely called Sebright) $v$ Sebright (1886) 12 PD 31 at 24, where Butt J maintained that "Public policy requires that marriages should not be lightly set aside, and there is in some cases the strongest temptation to the parties more immediately interested to act in collusion in obtaining a dissolution of the marriage tie. These reasons necessitate great care and circumspection on the part of the tribunal, but they in no wise alter the principle or the grounds on which this, like any other contract, may be avoided."

${ }^{41}$ Reiterating his words in Re K, A Local Authority v N [2005] EWHC 2956 (Fam) at para 93.

${ }_{42}$ See chapter 1, Consultation Paper, Forced Marriage: A Wrong not a Right (FCO/Home Office, 2005), where it is stated that those who force others to marry and those who assist them may be found guilty of such offences as kidnapping, child abduction, false imprisonment, assault, battery and other more serious offences of personal violence, threats to kill, various public order offences, harassment contrary to the Protection from Harassment Act 1997, child cruelty and blackmail. The list is not exhaustive.
} 
hell”.

\section{CONCLUSION}

Forced marriages are a clear breach of the human rights of young people. The Universal Declaration of Human Rights, Article 16 (2) states that:

"Marriage shall be entered into only with the free and full consent of the intending spouses."

Whilst the General Recommendation No 21, of the UN Convention on the Elimination of All Forms of Discrimination Against Women provides that:

“A woman's right to choose a spouse and enter freely into marriage is central to her life and her dignity and equality as a human being."

And the UN Convention on the Rights of the Child, Article 19 maintains that

"State parties shall take all appropriate legislative, administrative, social and educational measures to protect the child from all forms of physical or mental violence, injury or abuse, neglect or negligent treatment, maltreatment or exploitation, including sexual abuse, while in the care of parent(s), legal guardian(s) or any other person who has the care of the child."

It is shocking, in the true sense of the expression, that the abuse of the human rights of young people continues today in the UK. The work of the government in the last nine years and particularly since 2005 has helped to reduce the abuse, however, there is yet more to be done. The non-exhaustive list of actions which need to be taken, provided by Dr Nazia Khanum in the Luton Study, should be required reading by all those interested in eradicating

${ }^{43}$ Article 12 of the European Convention on Human Rights (ECHR) provides that "Men and women of marriageable age have the right to marry and to found a family, according to the national laws governing the exercise of that right." It is arguable that this right includes not only the the right not to marry but also the requirement of free and full consent to any marriage as is required by the underlying principles of the ECHR of self-determination and human dignity. See also Liberty's response to the Joint Home Office and Foreign \& Commonwealth Office Consultation on Forced Marriage, December 2005:

http://www.liberty-human-rights.org.uk/pdfs/policy06/forced-marriage-consultation 


\section{THE DENNING LAW JOURNAL;}

this abhorrent and heinous practice. ${ }^{44}$ Her recommendations, which include the involvement of all support services, the education of women, the encouragement of good parenting, and the involvement of communities' and faith leaders, should be urgently followed up in the interests of all those victims, and potential victims, of forced marriages and its associated violence if they are to become empowered and able to take charge of their own future.

${ }^{44}$ Nazia Khanum - Forced marriage, family cohesion and community engagement: national learning through a case study of Luton (2008)//www.luton.gov.uk/ 